\title{
Flow and impact analysis
}

\author{
Lisa Deutsch ${ }^{1,2}$ and Max Troell1,3
}

\begin{abstract}
${ }^{1}$ STOCKHOLM RESILIENCE CENTRE, STOCKHOLM UNIVERSITY, STOCKHOLM, SWEDEN
${ }^{2}$ NORDIC INSTITUTE FOR LATIN AMERICAN STUDIES, STOCKHOLM UNIVERSITY, STOCKHOLM, SWEDEN ${ }^{3}$ BEIJER INSTITUTE OF ECOLOGICAL ECONOMICS, THE ROYAL SWEDISH ACADEMY OF SCIENCES, STOCKHOLM, SWEDEN
\end{abstract}

\section{Key methods discussed in this chapter}

Physical trade flows, multi-regional input-output analysis, environmentally extended multi-regional input-output analysis, environmental footprints, Life Cycle Assessment, energy return on investment, multi-scale integrated analysis of societal and ecosystem metabolism, global commodity chain analysis

\section{Connections to other chapters}

Methods for flow and impact analysis can require input from, be used as input into, be combined with and/or contain similar data as several other methods in this book. Environmental footprints and Life Cycle Assessment (LCA) studies, for example, need the ecological data generated from methods in ecological field data collection (Chapter 6) to convert material flows into environmental footprints and establish environmental relevance and impact for LCAs. Physical trade flows can be used as input into comparative case study analysis (Chapter 20), statistical analysis (Chapter 18), dynamical systems modelling (Chapter 26) and livelihood analysis (Chapter 32). Moreover, network analysis (Chapter 23) can be combined with physical trade flows to discern social-ecological linkages across scales. Also, related or similar information can be found in historical assessments (Chapter 25), while environmental footprints and some LCA impact categories are related to spatial mapping and analysis (Chapter 24).

\section{Introduction}

Flow and impact analysis is mainly used to measure and monitor how ecosystems are linked to and support human well-being and are affected by human-nature interactions. Flows are composed of inputs (e.g. energy and material resources), outputs (products and services produced) and wastes (e.g. emissions associated with production). In the conceptual causal chain from natural resource flows to impacts, extraction, production and emissions flows affect various biophysical structures or processes. This in turn has effects 


\section{SUMMARY TABLE: FLOW AND IMPACT ANALYSIS}

\begin{tabular}{|c|c|}
\hline DISCIPLINARY BACKGROUND & KNOWLEDGE TYPE \\
\hline $\begin{array}{l}\text { The methods in this chapter are derived } \\
\text { from or have most commonly been used in: } \\
\text { Human, Political and Systems Ecology, } \\
\text { Cultural and Physical Geography, } \\
\text { Physics, Geology, Chemistry, Hydrology, } \\
\text { Ecological Economics, Political } \\
\text { Economy, Sociology }\end{array}$ & $\begin{array}{l}\text { The methods in this chapter are primarily } \\
\text { used to generate the following types of } \\
\text { knowledge: } \\
\text { - Descriptive } \\
\text { - Explanatory } \\
\text { - Prescriptive }\end{array}$ \\
\hline RESEARCH APPROACH & PURPOSE OF METHOD \\
\hline $\begin{array}{l}\text { The methods in this chapter originate } \\
\text { from or most commonly adopt the } \\
\text { following research approaches: } \\
\text { - Analytical/objective } \\
\text { - Interpretive/subjective }\end{array}$ & $\begin{array}{l}\text { The most common purposes of using the } \\
\text { methods in this chapter are: } \\
\text { - Data collection/generation } \\
\text { - System understanding } \\
\text { - Policy/decision support }\end{array}$ \\
\hline TEMPORAL DIMENSION & SYSTEMIC FEATURES AND PROCESSES \\
\hline $\begin{array}{l}\text { The methods in this chapter are most } \\
\text { commonly applied to the following } \\
\text { temporal dimensions: } \\
\text { - Present (typically within the last } \\
5-10 \text { years) } \\
\text { - Recent past (post-1700s) }\end{array}$ & \multirow{2}{*}{$\begin{array}{l}\text { While most methods can do many } \\
\text { things, the methods in this chapter are } \\
\text { particularly good (i.e. go-to methods) for } \\
\text { addressing the following: } \\
\text { - Social-ecological dependence } \\
\text { and impact } \\
\text { - Multiple scales and levels or } \\
\text { cross-level interactions } \\
\text { - Social-ecological interactions } \\
\text { over time } \\
\text { - Evaluating policy options }\end{array}$} \\
\hline $\begin{array}{l}\text { The methods in this chapter are primarily } \\
\text { either or both: } \\
\text { - Non-spatial } \\
\text { - Explicitly spatial } \\
\text { The methods in this chapter are most } \\
\text { commonly applied at the following } \\
\text { spatial scales: } \\
\text { - Local } \\
\text { - Regional (provincial/state } \\
\text { to continental) } \\
\text { - Global } \\
\text { - Multiple places/sites around the world }\end{array}$ & \\
\hline
\end{tabular}


(e.g. reduction of ecosystem function and provision of ecosystem services) that result in various impacts on both ecological and social systems (e.g. human well-being). Studies can be performed over an entire product life cycle, from production and processing to consumption and waste. However, not all studies encompass the entire cycle, including impact analysis.

This large and diverse group of methods shares a common family tree with roots in both social and natural science (Haberl et al. 2019). In the natural sciences, methods arose from a variety of disciplinary fields, e.g. biology, systems ecology and hydrology (Falkenmark 2003). The aim was to collect empirical data on fundamental biophysical processes and stocks (e.g. energy: Odum 1971), nutrient cycles (nitrogen: Galloway et al. 2014) and other 'embodied' natural resources or affected systems tied to the impacts of human activities on the biosphere. These studies did not focus on natural cycles, but on resource flows both directly and indirectly related to human activities. Deutsch et al. (2010), for example, quantified global hydrological flows to give context to the share of embodied water in livestock production for human consumption.

Studies based in social science originally focused on the role of resource use for societal development, e.g. industrial metabolism (Ayres 1994). Methods also arose in different disciplines as researchers analysed, for example, unequal ecological exchange (Martinez-Alier 2002) and global commodity chains (Gereffi 2018) based in world systems theory (Hopkins and Wallerstein 1977). Today, flow and impact studies are common in the interdisciplinary fields of ecological economics (Jansson 1991), human ecology (Rees 1992), politicaleconomic sociology (Hirschman 1980) and political ecology (Peterson 2000).

Flow and impact studies include a large variety and number of different methods that can be deployed at multiple spatial scales to track the accelerating use of natural and social resources. There are methods focused at farm level (e.g. water use for animal feed (Ran et al. 2013)), at the national scale (e.g. the ecological footprint of Swedish land use for food consumption (Deutsch and Folke 2005)), at regional level (e.g. the environmental footprint of EU consumption of biomass for non-food purposes (Bruckner et al. 2019)) and at the global scale (e.g. 24 indicators depicting the Great Acceleration (Steffen et al. 2015a); nine proposed planetary boundaries (Steffen et al. 2015b)).

Studies can use single methods or metrics, such as household incomes, corporate market values, GDP, human appropriation of land, net primary productivity, fisheries catch or energy use, to name just a few. Studies also use methods that combine several metrics to generate multi-dimensional analyses of multiple resource flows into and out of socio-economic systems and emissions (e.g. carbon footprints). Methods can show where resources are used and/or emitted (e.g. multi-regional input-output models) and what the impacts are (e.g. impact categories in LCAs). Moreover, there are methods that are now capable of accounting for upstream flows. This enables the analysis of not only the entire supply chain and product life cycle but also the unintended or indirect spill-over effects into other systems than those included as direct producers, processors and consumers in the studied social-ecological systems (SES) (Godar et al. 2015).

This chapter describes some of the main research approaches and gives examples of methods used for flow and impact analysis. The majority of methods generate descriptive accounting studies for decision support. Flow and impact methods can track natural resource and human capital flows both directly and indirectly related to human activities, and associated direct and indirect impacts. Studies can track changes over time and space and simultaneously at different scales. Some studies are change-oriented and explicitly intend to communicate information (e.g. 
environmental footprint and LCA-based eco-labelling/certification) and even prescribe preferred options (environmental footprint and LCA). Whereas the methods are mostly analytical, there is certainly some subjective interpretation (e.g. LCA has an 'interpretation' phase where information from the life cycle inventory and/or the life cycle impact assessment is evaluated).

\section{SES problems and questions}

Flow and impact analysis methods can have widely differing goals and uses, from global-level scanning (planetary boundaries), to equitable sharing of resources between nations (environmental footprints), to product-level management tools (LCAs). They are mainly used to support decision- and policymaking and monitoring efforts. They can also be used in different phases of problem solving: (a) problem identification and agenda setting, by influencing the worldviews of consumers and policymakers (e.g. environmental footprints), (b) design of policy tools or policies (e.g. an LCA of public-school food procurement), and (c) monitoring, for feedbacks and learning on the impacts of different production methods (e.g. an LCA of salmon farming).

The following are examples of problems and questions typically addressed by some of the main methods discussed in this chapter:

- Are producers and consumers able to escape local biophysical ecosystem limits using trade? (e.g. can cities maintain food security with food trade? (physical trade flows: Porter et al. 2014))

- What is the level of diversity of animal feed supply sources for Thai jumbo shrimp aquaculture production? (physical trade flows: Deutsch et al. 2007; also see Case study 30.1)

- Are consumers able to dislocate the environmental impacts of their consumption to production sites abroad? And who is affected globally? (physical trade flows: Godar et al. 2015)

- Can water-scarce countries 'save' water at global scale by importing products from countries where water is abundant? (environmental footprints: Hoekstra and Mekkonen 2012)

- How do global value chains affect a country's own environment? (environmental footprints: Deutsch and Folke 2005)

- What are the greenhouse gas emissions per kilogram of fish produced in an intensive salmon aquaculture production system? (LCA: Newton and Little 2018)

- Which part of the product life cycle of salmon aquaculture production requires the most energy use: manufacture of feed, production site or processing? (LCA: Pelletier et al. 2009)

- Which product is most sustainable based on predefined sustainability criteria? (LCA)

\section{Brief description of key methods}

The largest group of methods used for flow and impact analyses falls into the category of material- and energy-flow accounting (MEFA) methods. This group includes material-flow accounting approaches that do not incorporate energy, and energy-flow accounting methods that focus specifically on energy flows. Material- and energy-flow accounting methods can assess the correlation between physical and monetary growth, e.g. if and how water use is related to GDP. Material-flow accounting approaches track biophysical material flows both directly and indirectly related to human activities. Energy-flow accounting illuminates the essential role that energy plays in our economy. 
There are two broad ways to track material and energy flows. The 'bottom-up' approach uses physical flows, whereas the 'top-down' approach traces resource flows through economic sectors with monetary input-output tables. Six common MEFA methods are described in this chapter:

1. Physical trade flows (PTF) typically map and link resource flows in material and spatial terms and can help to discern levels of dependence on different ecosystems for production and consumption.

2. Large international input-output (IO) databases enable multi-regional input-output (MRIO) analyses between nations and can account for bilateral trade relationships between several countries.

3. Environmentally extended multi-regional input-output (EE-MRIO) models complement monetary sectoral data with environmental and social indicators.

4. Environmental footprints (EF) can quantify levels of dependence on different types of ecosystem support (e.g. freshwater), illuminate support that is located in different places and linked through trade, and balance local, national and global resource budgets.

5. Life Cycle Assessment (LCA) quantifies environmental impacts associated with products, processes or activities; the main environmental impacts investigated in LCA are greenhouse global warming potential, water use, energy consumption, acidification and abiotic depletion.

6. Energy return on investment (EROI) is the ratio of the amount of usable energy obtained to the amount of energy required to obtain that energy, where the focus is not on the total amount of primary energy used, but on the energy gained by society.

Another type of flow and impact method is multi-scale integrated analysis of societal and ecosystem metabolism (MuSIASEM). This integrated accounting method simultaneously represents the metabolic pattern of social, economic, socio-metabolic and biophysical flows (e.g. labour, value added, energy use) and their interrelations with the complex system (society) interacting with its environment, e.g. the water-energy-food nexus.

Lastly, there are several 'global chain methods' that can analyse international trade and production networks of a specific commodity and map how people, places and processes are interlinked in the global economy. Global commodity chain (GCC) analysis maps what resources are produced and consumed, who governs, wields power and accumulates capital within the entire commodity chain from production to consumption, and where these processes occur. Table 30.1 provides a summary of key methods used in flow and impact analysis.

Whereas most material-flow and energy-flow accounting studies cover very recent years, with some exceptions from the 1900s (Krausmann et al. 2009) and the 1960s, many global chain studies are historical (Marichal, Topik, and Frank 2006; Topik 2008). Furthermore, some studies have used a single method but many studies combine multiple methods and indicators in an effort to yield more comprehensive inventories and impact assessments. Physical trade flows, for example, can be used to quantify the material flows needed for input into environmental footprint calculations of land areas, which could then be used as an input into LCA inventories. 
Table 30.1 Summary of key methods used in flow and impact analysis

\begin{tabular}{|c|c|c|}
\hline Methods & Description & References \\
\hline $\begin{array}{l}\text { Physical trade } \\
\text { flows }\end{array}$ & $\begin{array}{l}\text { Physical trade flow (PTF) methods can trace the size } \\
\text { and composition of traded goods, i.e. imports and } \\
\text { exports. Methods exclude domestic production and } \\
\text { total consumption or use. PTF focuses only on goods } \\
\text { moved in/outside relevant borders (e.g. nation, city). } \\
\text { PTF can use: } \\
\text { - National and international physical trade flow } \\
\text { data } \\
\text { - Adjusted PTF data (e.g. with bilateral trade flow } \\
\text { matrices) } \\
\text { - Input-output tables (alone or as input into multi- } \\
\text { regional input-output models) } \\
\text { A hybrid of sources, especially if one source is } \\
\text { incomplete }\end{array}$ & $\begin{array}{l}\text { Key introductory text } \\
\text { Kastner, Kastner, and } \\
\text { Nonhebel } 2011 \\
\text { Applications to SES } \\
\text { Deutsch et al. 2007; } \\
\text { Porter et al. 2014; } \\
\text { Godar et al. 2015; } \\
\text { Gephart et al. 2017; } \\
\text { trase.earth }\end{array}$ \\
\hline $\begin{array}{l}\text { Multi-regional } \\
\text { input-output } \\
\text { anlysis } \\
\text { Environmentally } \\
\text { extended multi- } \\
\text { regional input- } \\
\text { output analysis }\end{array}$ & $\begin{array}{l}\text { Today, large international input-output (IO) databases } \\
\text { enable multi-regional input-output (MRIO) analyses } \\
\text { between nations and can account for bilateral trade } \\
\text { relationships between several countries. } \\
\text { MRIO can use: } \\
\text { - Physical input-output models } \\
\text { (e.g. based on FAOSTAT) } \\
\text { - Monetary input-output models } \\
\text { (e.g. EXIOBASE) } \\
\text { - A hybrid of sources, especially if one source is } \\
\text { incomplete (e.g. FABIO) } \\
\text { Environmentally extended multi-regional input- } \\
\text { output (EE-MRIO) models can complement monetary } \\
\text { sectoral data with environmental and social } \\
\text { indicators. }\end{array}$ & $\begin{array}{l}\text { Key introductory text } \\
\text { Haberl et al. } 2019 \\
\text { Applications to SES } \\
\text { Kastner et al. 2014; } \\
\text { Stadler et al. } 2018 \\
\text { (EXIOBASE 3); } \\
\text { Bruckner et al. } 2019 \text { (FABIO); } \\
\text { Kummu et al. } 2020\end{array}$ \\
\hline $\begin{array}{l}\text { Environmental } \\
\text { footprints }\end{array}$ & $\begin{array}{l}\text { Environmental footprints (EF) calculate the } \\
\text { biological capacity needed to produce materials } \\
\text { and/or assimilate waste from a given population's } \\
\text { consumption of products (i.e. domestic production + } \\
\text { imports - (re-)exports). } \\
\text { Environmental footprints are calculated in two main } \\
\text { ways: } \\
\text { - Bottom-up based on physical flows } \\
\text { - Top-down using (MR)IO } \\
\text { Material flows are then combined with other } \\
\text { methods, e.g. hydrological data on crop-water use } \\
\text { to quantify the freshwater needed to generate a } \\
\text { product or service. } \\
\text { There are several footprints (e.g. ecological footprint } \\
\text { of land areas, water footprint/virtual water, nitrogen } \\
\text { and carbon footprints). }\end{array}$ & $\begin{array}{l}\text { Key introductory text } \\
\text { Wiedmann and Lenzen } 2018 \\
\text { Applications to SES } \\
\text { Deutsch and Folke } 2005 \text { (land } \\
\text { and sea areas); } \\
\text { Hoekstra and Mekkonen } 2012 \\
\text { (water); } \\
\text { Galloway et al. } 2014 \text { (nitrogen) }\end{array}$ \\
\hline
\end{tabular}


Table 25.1 (Continued)

\begin{tabular}{|c|c|c|}
\hline Methods & Description & References \\
\hline $\begin{array}{l}\text { Life Cycle } \\
\text { Assessment }\end{array}$ & $\begin{array}{l}\text { Life Cycle Assessment (LCA) aims to be a } \\
\text { comprehensive impact assessment tool for } \\
\text { researchers and policymakers. LCA begins at the } \\
\text { 'cradle' (point of primary resource extraction) } \\
\text { of a product or service and extends along the } \\
\text { supply chain to encompass all life-cycle stages. } \\
\text { LCA can identify and assess the environmental } \\
\text { impacts associated with a product, process or } \\
\text { activity by quantifying raw materials, energy and } \\
\text { waste released into the air, water and soil. } \\
\text { Chosen impact categories vary widely, but } \\
\text { commonly include resource depletion and } \\
\text { emissions-related environmental concerns and } \\
\text { toxicological potentials (e.g. greenhouse global } \\
\text { warming potential, water footprint, energy } \\
\text { consumption, acidification, abiotic depletion). } \\
\text { Unlike many other biophysical accounting } \\
\text { tools, LCA is internationally standardised } \\
\text { (ISO 14040-14044). }\end{array}$ & $\begin{array}{l}\text { Key introductory text } \\
\text { Curran } 2012 \\
\text { Applications to SES } \\
\text { Pelletier et al. 2009; } \\
\text { Henriksson et al. 2018; } \\
\text { Newton and Little 2018 }\end{array}$ \\
\hline $\begin{array}{l}\text { Energy return on } \\
\text { investment }\end{array}$ & $\begin{array}{l}\text { Energy return on investment (EROI) is the ratio } \\
\text { of the amount of usable energy (i.e. the ratio } \\
\text { of energy obtained to the amount of energy } \\
\text { required to obtain that energy). The main focus } \\
\text { is not the total amount of primary energy used, } \\
\text { but the energy gained by society. }\end{array}$ & $\begin{array}{l}\text { Key introductory text } \\
\text { Odum } 1971 \\
\text { Applications to SES } \\
\text { Hall 2011; } \\
\text { Pelletier et al. } 2011\end{array}$ \\
\hline $\begin{array}{l}\text { Multi-scale } \\
\text { integrated } \\
\text { analysis of societal } \\
\text { and ecosystem } \\
\text { metabolism }\end{array}$ & $\begin{array}{l}\text { Multi-scale integrated analysis of societal and } \\
\text { ecosystem metabolism (MuSIASEM) integrates } \\
\text { social, economic and socio-metabolic and } \\
\text { biophysical flows (e.g. labour, value added, energy } \\
\text { use). Although it can use some of the MEFA } \\
\text { methods, studies are typically context specific. }\end{array}$ & $\begin{array}{l}\text { Key introductory text } \\
\text { Gerber and Scheidel } 2018 \\
\text { Applications to SES } \\
\text { Giampietro and Bukkens } 2014\end{array}$ \\
\hline $\begin{array}{l}\text { Global commodity } \\
\text { chains }\end{array}$ & $\begin{array}{l}\text { Global commodity chain (GCC) methods can } \\
\text { map not only what resources are produced and } \\
\text { consumed and where, but also who governs, } \\
\text { wields power and accumulates wealth or capital } \\
\text { within the entire commodity chain, from } \\
\text { production to commercialisation and consumption. } \\
\text { GCC also identifies the external institutional } \\
\text { context in which the chain operates. }\end{array}$ & $\begin{array}{l}\text { Key introductory text } \\
\text { Gereffi } 2018 \\
\text { Applications to SES } \\
\text { Topik 2008; } \\
\text { Gereffi 2018; } \\
\text { World Bank } 2019\end{array}$ \\
\hline
\end{tabular}

\section{Limitations}

Flow and impact analysis methods alone do not fully integrate human and ecological dimensions and do not account for many interdependencies between social-ecological processes. The most obvious shortcoming is that social-ecological researchers performing flow and impact studies must often use methods that were not fundamentally designed to analyse SES. Instead, they often use and adapt methods with a singular approach, e.g. an approach 
designed for a capitalist market system that solely tracks indicators of economic value (GDP, market value, commodity prices).

Moreover, data that are most readily available for use in flow and impact studies may not be available at the appropriate social and ecological scales. The specific location of where resources originate matters for ecosystems and societies, particularly in terms of understanding who benefits from resource extraction, who governs resource use and what ecosystem effects are experienced. To be able to discern the social-ecological effects of soybean production in the Brazilian Cerrado biome, for example, exports, ownership, land-cover changes, tax policies and company profits must all be traceable to enable the linking of specific products to specific agro-ecosystems and particular actors such as land owners, land managers, service contractors, processors or multi-national companies supplying seeds. Most nations do not track flows and impacts at subnational level and states allow corporations to hinder traceability of products to landscapes, producers, inputs and profits as proprietary knowledge. Thus, if data are not available or accessible, studies must upscale (or downscale) data to another level with unknown relevance, e.g. most studies of food consumption at the city level are based on adjusted national-level consumption statistics (Porter et al. 2014).

Social-ecological systems researchers often combine several methods and data sources to adequately reflect the current complexity of flows and the multi-dimensional nature of effects (e.g. how to combine toxicity studies related to chemical use and pollution at the individual insect species level with national-level data on volumes of pesticide use). To modify data for relevancy, researchers also use additional methods (e.g. expert interviews) to gather additional data (e.g. particular species of fish) or conversion factors (e.g. city-level consumption). This is time and resource intensive (e.g. combining LCA studies (ecological effects of different production methods) with MRIO is very data intensive) and requires expertise in several methods.

If methods or data cannot be meaningfully modified, it places significant limitations on the conclusions that can be drawn. For instance, although environmental footprints have successfully illuminated the scale of the social-ecological impacts of the human enterprise for the general public and decision-makers, it is doubtful whether certain flows and impacts (e.g. the use of chemicals and biodiversity loss) can actually be meaningfully converted into environmental footprints (e.g. land or sea areas). As for LCA, while modern software with built-in inventory databases and impact assessment methods has simplified the LCA process, the rigour of these models is highly dependent on data quality. The use of the generic data available in many public and commercial life-cycle inventory databases may therefore provide a starting point for scoping analyses, but more context-specific data are required for robust modelling of specific production systems and technologies. Moreover, there is a need for standardisation of methodologies with respect to key model assumptions, scope and allocation methods.

Data availability is a major challenge for many flow and impact studies. In addition to the need for social-ecological relevance and the unavailability of data at relevant scales discussed above, there are general issues of: (a) data quality, (b) access fees for quality data, (c) restricted access, and (d) a paucity of historical data. Data on waste and emissions are also highly fragmentary, thus limiting studies that wish to include these or to get a full mass balance accounting (Krausmann et al. 2017).

There are many national statistical bureaus and quite a few international sources for data. The United Nations (UN) Food and Agriculture Organization has several free online physical trade flow databases based on self-reported national data, e.g. FAOSTAT and FISHBASE. The UN Environment Programme (UNEP) has a material flow accounting database. The OECD has an input-output database, and the World Bank, EUROSTAT and COMTRADE also have databases. Although these sources are sometimes inaccurate, they are 


\section{Case study 30.1: The dependence of intensive shrimp and salmon aquaculture production in Thailand and Norway on access to fishmeal imports from South American marine ecosystems}

Seafood is the most popular food commodity traded in the world, with aquaculture (or farmed seafood) being the fastest growing food sector globally (Troell et al. 2014). In fact, every other bite of fish we take today is from aquaculture. Jumbo shrimp and salmon are two of the most economically valuable aquaculture products (by weight) and Thailand and Norway are dominant producer countries of shrimp and salmon, respectively. Although non-fish substitutes are emerging, both of these products still depend on fishmeal as a key feed ingredient.

In a study by Deutsch et al. (2007), global production, trade and consumption of fishmeal for shrimp and salmon aquaculture production were traced from 1980 to 2000 as the aquaculture industries developed in Thailand and Norway. Despite the two nations having very different socio-economic and cultural backgrounds, social-ecological resource bases and geographic locations, and producing two entirely different products, there were some significant similarities:

- Shrimp and salmon aquaculture use the same fishmeal in feed pellets. Moreover, these are similar to chicken and pig feeds, so aquaculture can now be likened to 'aquatic livestock'.

- Thailand and Norway were both able to increase production (i.e. escape the limitations of own local fishing waters) and expand production and export through access to global markets and trade.

- There was no 'north-south' difference in supply sources of fishmeal. Shrimp farms in Thailand imported fishmeal from the same marine ecosystem as Norwegian salmon farms.

The study revealed that key products and producers are highly dependent on the same marine ecosystem, namely the south-east Pacific Ocean, for their key input, fishmeal. Using FISHBASE, fishmeal use and physical trade flows were tied to actual species of wild fish and linked to the locations of marine ecosystems needed to produce them, and tied to agrofood production systems (aquaculture). Thus, the physical trade flows study illuminated invisible marine subsidies in feed production and patterns of ecosystem support and flows.

The fact that the south-east Pacific Ocean (via Peru and Chile) supplies much of the world with fishmeal is an economic and ecological vulnerability, with both a reduced diversity of suppliers and increased pressure on a single marine area. Most people do not realise the dependence of aquaculture on fishmeal derived from distant marine ecosystems. Furthermore, although volumes of fish imports were traced, the study could not separate fishmeal use in aquaculture from other animal production systems

often the only available or free data sources. More accurate, high-resolution data are gathered by private consultants and trade associations, but have (sometimes exorbitant) access fees. Thus, for some studies, there may be no or limited access to data on major actors with the most power in the global chain. Furthermore, since free-trade zones exist, some trade data completely lose 


\section{SHRIMP AQUACULTURE IN THAILAND}
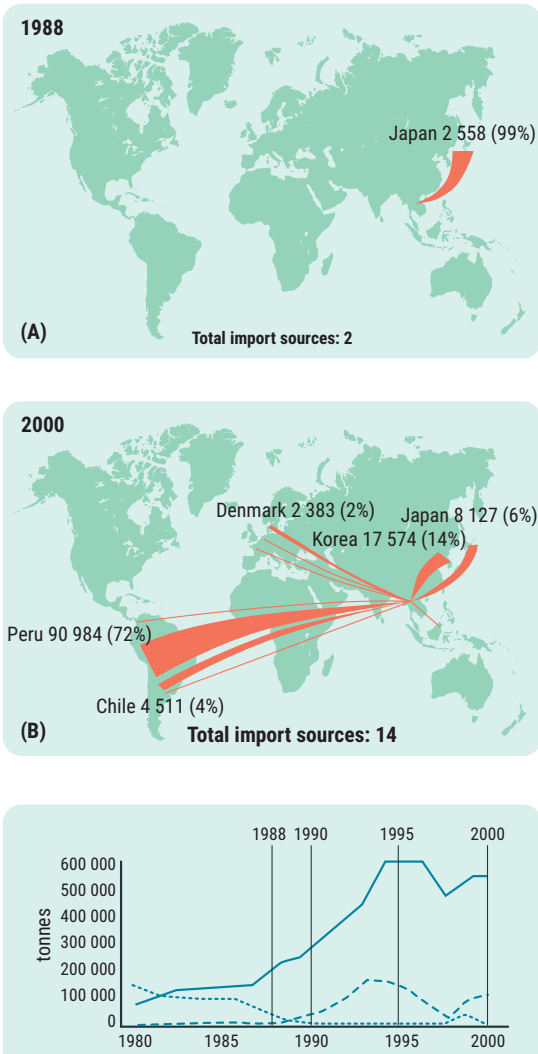

(C)

\section{SALMON AQUACULTURE IN NORWAY}
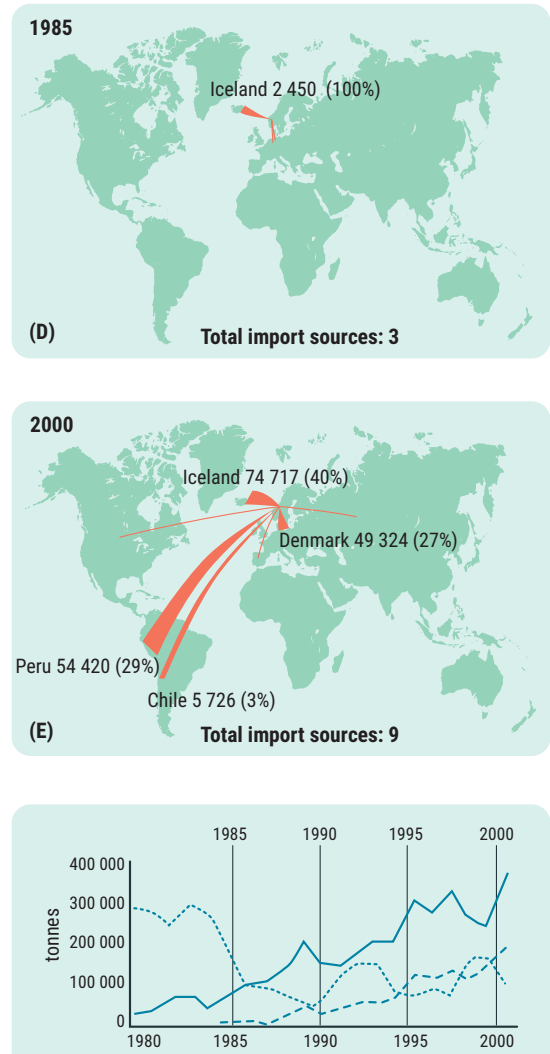

(F)

Figure 30.1 Fishmeal imports and import sources for Thailand (A and B) and Norway (D and E); fishmeal imports, exports and consumption for Thailand (C) and Norway (F) (adapted from Deutsch et al. 2007)

(chicken and pig feeds also contain fishmeal), nor tie consumption to specific aquaculture producers because companies would not reveal actual use. This information is still not available today (Fry et al. 2016).

Figure 30.1 shows the imported fishmeal and import sources for Thailand in 1988 (A) and 2000 (B) and for Norway in 1985 (D) and 2000 (E); and fishmeal imports, exports and consumption from 1980 to 2000 for Thailand (C) and Norway (F). Fishmeal amounts are in metric tonnes and numbers in parentheses denote percentages of total imports.

their origin, e.g. links to production systems. The current institutional framework for trade, i.e. the World Trade Organization, does not allow trade restrictions on the basis of production methods and data have therefore not been traced in this way. Another widespread problem is a lack of historical data prior to the 1960s, especially at larger scales, in digital format or in several languages, e.g. major databases like FAOSTAT start in 1961. 


\section{Resource implications}

All the methods in Table 30.1, except for some global commodity chain methods, require researchers to have advanced data-processing and analytical skills because desired datasets are digital, large and highly detailed. Certain methods require one or more areas of specific expertise (e.g. an ecological economist who understands the links between biophysical and economic flows, such as MuSIASEM). To gather data may thus require multiple skills from the same researcher or a skilled team of researchers and practitioners. It takes time, resources and trust to build an interdisciplinary team of researchers that not only work well together but also transcend their disciplines, truly inform one another and reach a joint understanding of the system. The sheer quantity of data needed can also require significant computer server capacity for data processing (e.g. adjusted physical trade flows, EE-MRIO). All these detailed, data-intensive studies are resource intensive and can be costly.

Moreover, historical analyses require rigorous source criticism on how the information has been selected. These analyses may require the use of a wide range of literature dealing with different historical epochs and places, and representing divergent perspectives and research traditions (e.g. agronomy, anthropology, archaeology, climate science, ecology, economics, geography and/or history).

\section{New directions}

Future directions for flow and impact methods are threefold: (a) increasing the comprehensiveness of the methods, (b) improving access to and relevance of data, and (c) increasing transdisciplinary efforts together with decision-makers and stakeholders.

Efforts to fully integrate social-ecological aspects into flow and impact analysis methods continue with some noteworthy successes. The recent development of the MRIO framework with environmentally extended multi-regional input-output (EE-MRIO) tables provides a more comprehensive linking of the global economy, labour inputs and associated impacts on ecosystems, and avoids double counting (Cabernard, Pfister, and Hellweg 2019). A recent policy application is Policy-Relevant Indicators for National Consumption and Environment (PRINCE) (prince-project.se). PRINCE links Swedish national input-output tables with EXIOBASE (an EE-MRIO) to estimate environmental pressures of consumption and production, and allocates those pressures to 60 'product groups' to show where in the world the environmental pressures occurred. The model informs Swedish policy development and monitoring, e.g. national environmental quality targets and national accounts.

Similarly, LCA has, since its emergence in the 1970s, moved from primarily being a tool for waste and energy-efficiency management to a more general eco-efficiency measurement decision-support framework. New developments in the LCA ISO standard include additional environmental as well as economic and social aspects (e.g. human health), and deepening its analytic capacity (e.g. considering behavioural aspects in the inventory modelling). However, it is debatable whether there is a limit to how comprehensive some methods or approaches can be.

Improvements in access to and the relevance of data are increasing the capability to trace flows and impacts at disaggregated levels spatially, temporally and physically. A notable application based on cooperation between researchers and corporate stakeholders is Spatially Explicit Information on Production to Consumption Systems (SEI-PCS) (Godar et al. 2015). This application traces material-flow analysis via the individual companies that export and import specific commodities. SEI-PCS data have been used by the Trase Initiative (Trase 2018) to map supply chains from the local subnational production regions through trading companies all the way to import nations (e.g. Brazilian soybeans, Indonesian palm oil). 
To date, flow and impact methods have not been widely developed in collaboration with decision-makers or societal stakeholders. However, inherently subjective aspects have recently been explicitly acknowledged (Pelletier, Bamber, and Brandão 2019) and even encouraged (Einarsson and Cederberg 2019) (e.g. the choice of weighting factors in LCA) in recognition of the need for guidance and transparency with regard to prioritisations that take place in decision-making. There is growing interest in exploring the benefits of a transdisciplinary approach that could address the need for combining methods and engaging skilled teams of researchers and practitioners in flow and impact studies.

\section{Key readings}

Goedkoop, M., R. Heijungs, M.A.J. Huijbregts, A. de Schryver, J. Struijs, and R. van Zelm. 2009. 'ReCiPe 2008 - A Life Cycle Impact Assessment Method which Comprises Harmonised Category Indicators at the Midpoint and the Endpoint Level.' Report I: Characterisation. file://C:/Users/ User/Downloads/ReCiPe_main_report_MAY_20131.pdf.

Kastner, T., M. Kastner, and S. Nonhebel. 2011. 'Tracing Distant Environmental Impacts of Agricultural Products from a Consumer Perspective.' Ecological Economics 70: 1032-1040.

Krausmann, F., S. Gingrich, N. Eisenmenger, K-H. Erb, H. Haberl, and M. FischerKowalski. 2009. 'Growth in Global Materials Use, GDP and Population During the 20th Century.' Ecological Economics 68(10): 2696-2705.

Marichal, C., S. Topik., and Z. Frank. 2006. 'Commodity Chains and Globalization in Historical Perspective.' In From Silver to Cocaine: Latin American Commodity Chains and the Building of The World Economy, 1500-2000, edited by S. Topik, Z.L. Frank, and C. Marichal, 1-24. Durham: Duke University Press.

Monfreda, C., M. Wackernagel, and D. Deumling. 2004. 'Establishing National Natural Capital Accounts Based on Detailed Ecological Footprint and Biological Capacity Assessments.' Land Use Policy 21(3): 231-246. www.sciencedirect.com/science/article/B6VB0-4BNVWBB-1/2/ e5a72c38dc783550ac0b0a6fd625ad4e.

\section{Acknowledgements}

The authors would like to thank Michelle Audouin for getting this chapter started and the critical enthusiasm of our discussions. Also, thanks are due to Tiina Häyhä for her advice on disentangling the multitude of methods. Lisa Deutsch's work was partially financed by the Swedish Research Council grant 'Agrofood Globalization through the Lens of the Soybean'.

\section{References}

Ayres, R.U. 1994. Industrial Metabolism: Theory and Policy, the Greening of Industrial Ecosystems. Washington: National Academy Press.

Bruckner, M., T. Häyhä, S. Giljum, V. Maus, G. Fischer, S. Tramberend, and J. Börner. 2019. 'Quantifying the Global Cropland Footprint of the European Union's Non-Food Bioeconomy.' Environmental Research Letters 14(4): 45011. doi:10.1088/1748-9326/ab07f5.

Cabernard, L., S. Pfister, and S. Hellweg. 2019. 'A New Method for Analyzing Sustainability Performance of Global Supply Chains and Its Application to Material Resources.' Science of The Total Environment 684: 164-177. doi:10.1016/j.scitotenv.2019.04.434.

Curran, M.A., ed. 2012. Life Cycle Assessment Handbook: A Guide for Environmentally Sustainable Products. Hoboken: John Wiley \& Sons. doi:10.1002/9781118528372.

Deutsch, L., M. Falkenmark, L.J. Gordon, J. Rockström, and C. Folke. 2010. 'Water-mediated Ecological Consequences of Intensification and Expansion of Livestock Production.' In Livestock in a Changing Landscape, Volume 1, edited by H. Steinfeld, H. Mooney, F. Schneider, and L. Neville, 97-110. Washington, DC: Island Press. www.fao.org/3/a-am074e.pdf. 
Deutsch, L., and C. Folke. 2005. 'Ecosystem Subsidies to Swedish Food Consumption from 1962 to 1994.' Ecosystems 8(5): 512-528. doi:10.1007/s10021-005-0035-4.

Deutsch, L., S. Gräslund, C. Folke, M. Huitric, N. Kautsky, M. Troell, and L. Lebel. 2007. 'Feeding Aquaculture Growth through Globalization: Exploitation of Marine Ecosystems for Fishmeal.' Global Environmental Change 17(2): 238-249. doi:10.1016/j.gloenvcha.2006.08.004.

Einarsson, R., and C. Cederberg. 2019. 'Is the Nitrogen Footprint Fit for Purpose? An Assessment of Models and Proposed Uses.' Journal of Environmental Management 240: 198-208. doi:10.1016/j. jenvman.2019.03.083.

Falkenmark, M. 2003. 'Freshwater as Shared between Society and Ecosystems: From Divided Approaches to Integrated Challenges.' Philosophical Transactions of the Royal Society B: Biological Sciences 358(1440): 2037-2049. doi:10.1098/rstb.2003.1413.

Fry, J.P., D.C. Love, G.K. MacDonald, P.C. West, P.M. Engstrom, K.E. Nachman, and R.S. Lawrence. 2016. 'Environmental Health Impacts of Feeding Crops to Farmed Fish.' Environment International 91: 201-214. doi:10.1016/j.envint.2016.02.022.

Galloway, J.N., W. Winiwarter, A. Leip, A.M. Leach, A. Bleeker, and J.W. Erisman. 2014. 'Nitrogen Footprints: Past, Present and Future.' Environmental Research Letters 9(11): 115003. doi:10.1088/1748-9326/9/11/115003.

Gephart, J.A., L. Deutsch, M.L. Pace, M. Troell, and D.A. Seekell. 2017. 'Shocks to Fish Production: Identification, Trends, and Consequences.' Global Environmental Change 42. doi:10.1016/j. gloenvcha.2016.11.003.

Gerber, J-F., and A. Scheidel. 2018. 'In Search of Substantive Economics: Comparing Today's Two Major Socio-metabolic Approaches to the Economy - MEFA and MuSIASEM.' Ecological Economics 144: 186-194. doi:10.1016/j.ecolecon.2017.08.012.

Gereffi, G. 2018. Global Value Chains and Development-Redefining the Contours of 21st Century Capitalism. New Delhi: Cambridge University Press.

Giampietro, M., and S.G. Bukkens. 2014. 'The Multi-scale Integrated Analysis of Societal and Ecosystem Metabolism.' In Resource Accounting for Sustainability Assessment, edited by M. Giampietro, R. Aspinall, J. Ramos-Martin, and S.G.F. Bukkens, 33-43. Abingdon: Routledge.

Godar, J.U., U.M. Persson, E.J. Tizado, and P. Meyfroidt. 2015. 'Towards More Accurate and Policy Relevant Footprint Analyses: Tracing Fine-scale Socio-environmental Impacts of Production to Consumption.' Ecological Economics 112: 25-35. doi:10.1016/j.ecolecon.2015.02.003.

Haberl, H., D. Wiedenhofer, S. Pauliuk, F. Krausmann, D.B. Müller, and M. Fischer-Kowalski. 2019. 'Contributions of Sociometabolic Research to Sustainability Science.' Nature Sustainability 2(3): 173-184. doi:10.1038/s41893-019-0225-2.

Hall, C.A.S. 2011. 'Introduction to Special Issue on New Studies in EROI (Energy Return on Investment).' Sustainability 3(10): 1773-1777. doi:10.3390/su3101773.

Henriksson, P.J.G., B. Belton, K. Murshed-E-Jahan, and A. Rico. 2018. 'Measuring the Potential for Sustainable Intensification of Aquaculture in Bangladesh Using Life Cycle Assessment.' Proceedings of the National Academy of Sciences of the United States of America 115(12): 2958-2963. doi:10.1073/ pnas.1716530115.

Hirschman, A. 1980 (originally published 1945). National Power and the Structure of Foreign Trade. Berkeley: University of California Press.

Hoekstra, A.Y., and M.M. Mekonnen. 2012. 'The Water Footprint of Humanity.' Proceedings of the National Academy of Sciences of the United States of America 109(9): 3232-3237. doi:10.1073/ pnas.1109936109.

Hopkins, T.K., and I. Wallerstein. 1977. 'Patterns of Development of the Modern World-System.' Review (Fernand Braudel Center) 1(2): 111-145.

Jansson, A.M. 1991. 'Ecological Consequences of Long-term Landscape Transformations in Relation to Energy Use and Economic Development.' In Linking the Natural Environment and the Economy, edited by C. Folke and T. Kåberger, 97-110. London: Kluwer Academic Publishers.

Kastner, T., M. Kastner, and S. Nonhebel. 2011. 'Tracing Distant Environmental Impacts of Agricultural Products from a Consumer Perspective.' Ecological Economics 70(6): 1032-1040.

Kastner, T., A. Schaffartzik, N. Eisenmenger, K-H. Erb, H. Haberl, and F. Krausmann. 2014. 'Cropland Area Embodied in International Trade: Contradictory Results from Different Approaches.' Ecological Economics 104: 140-144. doi:10.1016/j.ecolecon.2013.12.003.

Krausmann, F., S. Gingrich, N. Eisenmenger, K-H. Erb, H. Haberl, and M. Fischer-Kowalski. 2009. 'Growth in Global Materials Use, GDP and Population during the 20th Century.' Ecological Economics 68(10): 2696-2705. 
Krausmann, F., H. Schandl, N. Eisenmenger, S. Giljum, and T. Jackson. 2017. 'Material Flow Accounting: Measuring Global Material Use for Sustainable Development.' Annual Review of Environment and Resources 42(1): 647-765. doi:10.1146/annurev-environ-102016-060726.

Kummu, M., P. Kinnunen, E. Lehikoinen, M. Porkka, C. Queiroz, E. Röös, M. Troell, and C. Weil. 2020. 'Interplay of Trade and Food System Resilience: Gains on Supply Diversity over Time at the Cost of Trade Independency.' Global Food Security 24: 100360. doi:10.1016/j. gfs.2020.100360.

Marichal, C., S. Topik., and Z. Frank. 2006. 'Commodity Chains and Globalization in Historical Perspective.' In From Silver to Cocaine: Latin American Commodity Chains and the Building of The World Economy, 1500-2000, edited by S. Topik, Z.L. Frank, and C. Marichal, 1-24. Durham: Duke University Press.

Martinez-Alier, J. 2002. The Environmentalism of the Poor: A Study of Ecological Conflicts and Valuation. Cheltenham: Edward Elgar.

Newton, R.W., and D.C. Little. 2018. 'Mapping the Impacts of Farmed Scottish Salmon from a Life Cycle Perspective.' The International Journal of Life Cycle Assessment 23(5): 1018-1029. doi:10.1007/ s11367-017-1386-8.

Odum, H.T. 1971. Environment, Power, and Society. New York: Wiley-Interscience.

Pelletier, N., E. Audsley, S. Brodt, T. Garnett, P. Henriksson, A. Kendall, K.J. Kramer, D. Murphy, T. Nemecek, and M. Troell. 2011. 'Energy Intensity of Agriculture and Food Systems.' Annual Review of Environment and Resources 36(1): 223-246. doi:10.1146/annurev-environ-081710-161014.

Pelletier, N., N. Bamber, and M. Brandão. 2019. 'Interpreting Life Cycle Assessment Results for Integrated Sustainability Decision Support: Can an Ecological Economic Perspective Help Us to Connect the Dots?' The International Journal of Life Cycle Assessment 24(9): 1580-1586. doi:10.1007/ s11367-019-01612-y.

Pelletier, N., P. Tyedmers, U. Sonesson, A. Scholz, F. Ziegler, A. Flysjo, S. Kruse, B. Cancino, and H. Silverman. 2009. 'Not All Salmon Are Created Equal: Life Cycle Assessment (LCA) of Global Salmon Farming Systems.' Environmental Science E Technology 43(23): 8730-8736. doi:10.1021/es9010114.

Peterson, G. 2000. 'Political Ecology and Ecological Resilience: An Integration of Human and Ecological Dynamics.' Ecological Economics 35(3): 323-336. doi:10.1016/S0921-8009(00)00217-2.

Porter, J.R., R. Dyball, D. Dumaresq, L. Deutsch, and H. Matsuda. 2014. 'Feeding Capitals: Urban Food Security and Self-provisioning in Canberra, Copenhagen and Tokyo.' Global Food Security 3(1). doi:10.1016/j.gfs.2013.09.001.

Ran, Y., L. Deutsch, M. Lannerstad, and J. Heinke. 2013. 'Rapidly Intensified Beef Production in Uruguay: Impacts on Water-Related Ecosystem Services.' Aquatic Procedia 1(0): 77-87. doi:10.1016/j. aqpro.2013.07.007.

Rees, W.E. 1992. 'Ecological Footprints \& Appropriated Carrying Capacity.' Environment E Urbanization 4(2): 121-130.

Stadler, K., R. Wood, T. Bulavskaya, C-J. Södersten, M. Simas, S. Schmidt, A. Usubiaga et al. 2018. 'EXIOBASE 3: Developing a Time Series of Detailed Environmentally Extended Multi-regional Input-output Tables.' Journal of Industrial Ecology 22(3): 502-515. doi:10.1111/jiec.12715.

Steffen, W., W. Broadgate, L. Deutsch, O. Gaffney, and C. Ludwig. 2015a. 'The Trajectory of the Anthropocene: The Great Acceleration.' Anthropocene Review 2(1). doi:10.1177/2053019614564785.

Steffen, W., K. Richardson, J. Rockström, S.E. Cornell, I. Fetzer, E.M. Bennett, R. Biggs, S.R. Carpenter, W. de Vries, and C.A. de Wit. 2015b. 'Planetary Boundaries: Guiding Human Development on a Changing Planet.' Science 347(6223): 1259855.

Topik, S. 2008. 'Historicizing Commodity Chains: Five Hundred Years of the Global Coffee Commodity Chain.' In Frontiers of Commodity Chain Research, edited by J. Bair, 37-62. Stanford: Stanford University Press.

Trase. 2018. The Trase Yearbook 2018. Sustainability in Forest-Risk Supply Chains: Spotlight on Brazilian Soy. https://yearbook2018.trase.earth.

Troell, M., R.L. Naylor, M. Metian, M. Beveridge, P.H. Tyedmers, C. Folke, K.J. Arrow et al. 2014. 'Does Aquaculture Add Resilience to the Global Food System?' Proceedings of the National Academy of Sciences 111(37): 13257-13263.

Wiedmann, T., and M. Lenzen. 2018. 'Environmental and Social Footprints of International Trade.' Nature Geoscience 11(5): 314-321. doi:10.1038/s41561-018-0113-9.

World Bank. 2019. World Development Report 2020: Trading for Development in the Age of Global Value Chains. Washington: World Bank. 